\title{
BORDERS AND BODIES: WOMEN, VIOLENCE, AND MARTYRDOM IN SHAUNA SINGH BALDWIN'S PARTITION FICTION
}

\author{
Debali Mookerjea-Leonard \\ James Madison University, Virginia, USA
}

\begin{abstract}
Through the lens of Shauna Singh Baldwin's fiction - "Family Ties" (1996) and What the Body Remembers (1999) — this paper addresses how for many women, national independence is a tale of trauma, how the country's freedom is inseparable from their loss of homeland through Partition, the loss of control over their bodies in the inter-community riots, and, finally, their loss of home through betrayal by their families. The paper examines how the predicament of women who died to preempt violation - whether through suicide, or murder by kin-men - celebrated as "martyrs," and those who suffered rejections within the family after the fact, disputes cultural representations of the home as "safe space" and the family as unreservedly loving.
\end{abstract}

Keywords: India, Partition, Shauna Singh Baldwin, Trauma, Women.

\section{RESUMEN}

A partir de la narrativa de Shauna Singh Baldwin (me centro en "Family Ties" de 1996 y What the Body Remembers de 1999) este artículo pone de manifiesto cómo para muchas mujeres la Independencia es un relato traumático: la libertad del país es inseparable del desplazamiento causado por la Partición, la pérdida de control sobre sus cuerpos durante la violencia sectaria y, finalmente, el repudio por las propias familias. Unas murieron para evitar agresiones sexuales (ya fuese por suicidio o por 'sacrificios de honor' perpetrados por los varones de su familia) y se convirtieron en "mártires;" otras, en cambio, sufrieron el rechazo de sus familiares después de haber sido violadas. Estas categorizaciones tan distintas ponen en entredicho la representación del hogar como "espacio seguro" y de la familia como un refugio de amor incondicional.

Palabras clave: India, Mujeres, Partición, Shauna Singh Baldwin, Trauma. 
In the aftermath of the sectarian violence in Noakhali, East Bengal, in the autumn of 1946, Mahatma Gandhi advised women facing the threat of intimate violence to commit suicide in order to preserve their chastity. He suggested that women "commit suicide by poison or some other means to avoid dishonour ... suffocate themselves or ... bite their tongues to end their lives" (Gandhi v. 92: 355). About a year later, on September 18, 1947, Gandhi, at a prayer meeting, again valorized Hindu and Sikh women's pre-emptive deaths as a sign of strength, saying that,

I have heard that many women who did not want to lose their honour chose to die. Many men killed their own wives. I think that is really great, because I know that such things make India brave. After all, life and death is a transitory game. Whoever might have died are dead and gone; but at least they have gone with courage. They have not sold away their honour. Not that their life was not dear to them, but they felt it was better to die than to be forcibly converted to Islam by the Muslims and allow them to assault their bodies. And so those women died. They were not just a handful, but quite a few. When I hear all these things I dance with joy that there are such brave women in India. (Gandhiv v. 96: 388-389)

Death, national honor, and patriarchal values coalesce in this tribute to suicide and murder. Gandhi not only sanctions violence, but he also rationalizes it as patriotism, interpreting women's chastity as the reservoir for national honor and their deaths as the articulation of their free choice. Rather than condemning the ongoing violence against women, Gandhi's response only raises more questions - questions of violence, of silences, of bodies, and of desires. ${ }^{1}$

However, not all vulnerable Sikh and Hindu women opted for "martyrdom," and many were abducted and/or converted by Muslims. But unlike the commemoration above, the torments of women who were "taken" have been, mostly, surrounded by silence. And after many abductees were "rescued" and repatriated to India, on state initiative, they were no longer welcome in their families. Using Shauna Singh Baldwin's short story "Family Ties" (1996) and her novel What the Body Remembers (1999), this paper examines the predicament of women who died to preempt violation and were, subsequently, lauded for their heroism, and those who suffered rejections within the family because they had experienced the forbidden "touch." 2 The paper addresses the question of how literary representation mediates

${ }^{1}$ For a detailed discussion of Gandhi's responses on the subject of violence against women during the Partition riots, see Mookerjea-Leonard (2010).

${ }^{2}$ In a haunting flashback in Sabiha Sumar's film Khamosh Pani (The Silent Waters, 2003), set in a Punjabi village Charkhi, in 1947, a young Sikh woman Veero stands on the edge of a well, where other Sikh women have also lined up to end their lives by drowning rather than fall prey to Muslims. Although urged by her father to jump, Veero hesitates, and finally, runs away but is captured by a group of young Muslim men. When the film opens in the late-1970s, Veero is Ayesha, a Muslim widow living in Charkhi, a Pakistani village since Partition, with a grown son, Saleem. And then, her brother Jaswant comes from India, looking for her. I cite this part of the plot of the film because it explores similar situations and offers alternative resolutions to the two plots presented in the discussion above. On the one hand, unlike Kusum Veero rejects martyrdom by fleeing the 
a cultural self-examination of the condition of women as a whole and how a place in the home is contingent on certain regimes of the body, most important among which is chastity.

\section{THE “GOOD-GOOD” WOMAN}

Set in Punjab, What the Body Remembers weaves the political history of latecolonial India - beginning in the late-1920s through 1947-, with the domestic conflict between Satya (meaning "truth") and Roop (meaning "form"), the co-wives of Sardarji. While the novel gives Satya a place of prominence, at the focus of this bildungsroman is Roop - her "education," her transformation from a compliant young woman given in marriage to a much older man (for the purpose of bearing him a male heir), to a bolder version of herself, much like the plain-spoken Satya- a metaphorical fusing of truth with form/beauty. Tracing through the two women's escalating animosities the growing fissures in inter-community relations, the novel navigates through the tumultuous 1930s and the political vicissitudes of the early to mid-1940s which culminate in the Partition. What the Body Remembers chronicles episodes of Partition's brutalities through the eyes of Roop who journeys from Pakistan to India in mid-August 1947. Violence comes close to home in Roop's personal confrontation with a mob, and through the loss of family members and friends. She realizes that women are subject to violence not only by members of the "other" community, but also by members of their own family.

An instance of this last is the death of Roop's sister-in-law Kusum, the wife of her brother Jeevan. In the midst of the inter-community riots surrounding the Partition, Jeevan returns to their village Pari Darvaza to take his father, his wife and sons and other relatives out of Pakistan. He fears that as Sikhs in a predominantly Muslim village his family might be subject to violence. He finds his ancestral home empty except for the corpse of his wife Kusum, "sliced into six parts, then arranged to look as if she were whole again." Jeevan is bewildered by the serenity of Kusum's demeanor in the face of such horrific violence, "she look[s] accepting ... Her hand [is] unclenched. Her feet [are] not poised to run. Her legs cut neatly at the thigh" (447). Jeevan holds Muslim rioters responsible for Kusum's dismemberment and death ${ }^{3}$ but he is mistaken, if only partly. Roop learns from her father, Bachan Singh, that Kusum was already dead when the Muslim mob arrived. The rioters mutilated Kusum's body and ripped out her womb, but they were desecrating a corpse. It was not the mob, but Roop and Jeevan's father, Bachan Singh, who killed Kusum, his daughter-in-law.

scene, and, on the other, unlike Chandini-Jehanara Veero-Ayesha, knowing that her family wanted her to die, does not plead with them for acceptance or lose her sanity, and when years later Jaswant implores her to return, citing their father's grief, she refuses.

${ }^{3}$ Jeevan also suspects his uncle, Shyam Chacha, a Hindu, could be responsible. 
Narrating the family's escape from the village, Bachan Singh tells Roop, "Kusum, she was my responsibility ... [she] was entrusted to me by Jeevan, she is young, still of childbearing age. I cannot endure even the possibility that some Muslim might put his hands upon her. Every day I had been hearing that the seeds of that foreign religion were being planted in Sikh women's wombs. No I said: I must do my duty" (Baldwin 1999: 455). And in order to pre-empt her violation by Muslim men and preclude her forcible conversion to Islam, Bachan Singh performs his "duty" — he kills her. "I called to Kusum" he tells Roop,

I told her what Sant Puran Singh said we Sikhs must do, and that I had to do it now. She understood. Always she made no trouble ... I said the first pauri ${ }^{4}$ of the Japjii to give me strength and guide my kirpan. ${ }^{6}$ Then she turned her back so I should not see her face, took off her chunni ${ }^{7}$ to bare her neck ... I raised my kirpan high above her head. Vaheguru ${ }^{8}$ did not stop it; it came down. Her lips still moved, as mine did, murmuring 'Vaheguru, Vaheguru,' as her head rolled from my stroke. (456)

By beheading her, Bachan Singh preempts Kusum's violation, and in so doing, defends the honor of his son, of his family, and that of the Sikh community. In inflicting "real but honourable death" upon Kusum, Bachan Singh averts her possible "symbolic death that marriage/[violation] and conversion entailed" (Menon and Bhasin 48). Further, he couches this familial/patriarchal violence in the language of her (and his) sacred duty regarding what "Sikhs must do" performed in the midst of items of religious significance: the prayer, the ceremonial sword, and even going so far as to justify it as divine will: "Vaheguru did not stop it." When narrating the event to another woman, his daughter Roop, Bachan Singh almost carefully emphasizes the voluntary nature of Kusum's "self-sacrifice": "She understood. Always she made no trouble." His seamless narrative of Kusum's obedient compliance and stoical heroism erases "the confusions of the moment, the uncertainty and fear felt by the victims and the frequent need for coercion before they agreed to become 'martyrs"' (Pandey 194). Discussing the episode of Kusum's "self-sacrifice," Deepti Misri notes that, "never do we hear any mention of her tears, nor any speculation about her grief over a life foreshortened for someone else's honor; we hear only of her unquestioning valor as she went to her death" (emphasis in the original; 81). This is the story that Bachan Singh wants Kusum's children to hear, of how their mother "went to her death just as she was offered it ... willingly ... for the izzat" of her quom ${ }^{10 "}$ (Baldwin 456). His is a narrative prepared, even selected, for posterity, one that elevates Kusum and views Bachan Singh as simply an instrument of divine

\footnotetext{
4 Section.

5 Prayer hymn

6 Ceremonial sword.

7 A long scarf used by women.

8 The Lord

9 Honor, respect, dignity.

10 People/Community/Nation.
} 
will, thereby, extricating him from blame. While Kusum was mostly docile - "never saying 'nahinji' or 'no-ji'" —, she had, earlier in the novel, also attempted to renegotiate patriarchal demands - "sometimes [she] did not obey 'fut-a-fut,' at once," (Baldwin 1999: 457)—, but in the end, she submits. Was Kusum's self-possession in the face of death preparedness for it, as Bachan Singh claims, or, was it simply resignation? Did she come to recognize that ultimately there was no escape from patriarchal violence? While ambiguities surrounding Kusum's seeming submission are sustained in the novel, Roop's reaction to her father's narration is illuminating. Listening to him speak of Kusum's death, Roop reflects, "Papaji thinks that for good-good women, death should be preferable to dishonor" (italics in original; 456). The father-in-law, acting on behalf of a repressive religious-patriarchy (the law of the Father), decides what the "good" — dutiful, obedient, chaste— daughter-in-law's duty should be, and, demands her death. ${ }^{11}$

Neither Bachan Singh's action nor Kusum's response is without precedence. In March 1947, 90 Sikh women from the village of Thoa Khalsa jumped into a well in order to escape falling into the hands of Muslim mobs ${ }^{12}$ - an actual incident that Baldwin's novel mentions in passing. Commenting on the recurrence of women's pre-emptive deaths, Ritu Menon and Kamla Bhasin note that "So powerful and general was the belief that safeguarding a woman's honour is essential to upholding male and community honour that a whole new order of violence came into play, by men against their own kinswomen; and by women against their own daughters or sisters and their own selves" (Menon and Bhasin 44-45). In Baldwin's novel, Bachan Singh tells Roop that it was not men alone who killed women members of their family, "the women were ready to kill too ... Old women were giving opium to younger women ... preparing them for martyrdom" (453). In such impossible circumstances, argue Menon and Bhasin, "to acquiesce is not to consent, and to submit is not necessarily to agree" (46). Gandhi's speech, cited at the beginning of this essay, bears testimony to the prevalence of women's pre-emptive suicides and the killing of women by their kin, and also reflects the social acceptance of the practice. His commemoration, however, was not an isolated act, Urvashi Butalia also notes how in contrast to the silence around "abducted" and violated women, "[c]hivalrous women, for example those who had committed mass suicides in order to save themselves from being converted to the 'other' religion, were the subject of

11 Shumona Dasgupta notes that Kusum "is 'martyred' in the same room in which Roop's mother died at childbirth, 'martyred' to an ambition to keep bearing sons thereby tying extraordinary instances of violence experienced by women during the Partition with everyday violence experienced by them as a consequence of their desire to be the ideal daughter, wife and mother" (46).

12 On 15 March 1947, The Statesman reported that, "The story of 90 women of the little village of Thoa Khalsa, Rawalpindi district ... who drowned themselves by jumping into a well during the recent disturbances has stirred the imagination of the people of Punjab. They revived the Rajput tradition of self-immolation when their menfolk were no longer able to defend them. They also followed Mr Gandhi's advice to Indian women that in certain circumstances even suicide was morally preferable to submission' (cited in Butalia, 1993: WS-16). 
much discussion. In remembrance services, in gurudwaras they were honoured and their shahidi (martyrdom) valorized" (1995: 62).

It is worth noting that while Bachan Singh seems vigilant about issues of family and community honor, he is content to let his cousin Revati Bhua distract the Muslim mob so that he and others can safely escape from the village, though he knows that the mob will capture Revati Bhua and convert her to Islam. Similarly, he leaves the defenseless Gujri, the domestic help who helped raise Bachan Singh's children after the death of his wife, by the wayside (her wish, he claims), aware that she will be picked up by the Muslims and violated and/or converted. Yet, violation and conversion are the very consequences he averts for Kusum. ${ }^{13}$ The reader, at this point, wonders: Why does he allow Revati Bhua's capture by the Muslim mob, and her (possible) conversion to Islam? Why does he abandon Gujri? What about being honorable? I suggest that because unmarried Revati Bhua and the widow Gujri are "man-less" women, their violation and/or conversion will not tarnish a man's honor, or that of the community, conceived fraternally, and, therefore, either woman is of little value. The novel thus exposes patriarchy's selective evaluation of women's worth based on the presence or absence of male guardians in their lives. Misri writes that, "In Bachan Singh's inventory of the Pari Darwaza women who voluntarily, even insistently, give up their own lives, safety, and freedom for the sake of others, what becomes amply evident is the dispensability of the women from whom such sacrifice was clearly expected" (81). And in every case —Kusum, Revati Bhua, and Gujri- Bachan Singh claims their "self-sacrifice" is of their choosing.

On the other hand, Revati Bhua and Gujri's "man-less" condition frees them from familial/patriarchal surveillance over their sexuality, and, thus, unlike Kusum, offers them the possibility of survival. Of the original six inhabitants of Singh's Pari Darvaza home - Revati Bhua, Bachan Singh, Gujri, Kusum, and her two young sons - only half that number arrives in Delhi. All three women $(\mathrm{Ku}-$ sum, Revati Bhua, and Gujri) are "lost” through Bachan Singh's actions or inertia. Singh brings to Delhi the only people who matter to him, his two grandsons. The male children are important because they will continue the bloodline, and for them, Bachan Singh preserves the family's untarnished reputation by eliminating even the possibility of the "taint" of rape through murdering their mother, Kusum. Roop's silent contemplations upon learning of the fate of Revati Bhua and Gujri, rupture repeatedly the cohesive narrative of women's "self-sacrifice" that Bachan Singh attempts to construct, going so far as to suggest that he might even be manipulating the truth, "Papaji is the teller of Revati Bhua's tale and he tells it as he wishes it repeated" (458) and even rises to the accusatory, "How could you leave [Gujri]?" (460). While these remain unspoken, Misri notes that "it is through such quiet hesitations on the part of the female listener that the patriarchal investments driving the men's narrations are laid bare" (78).

13 Shumona Dasgupta notes that Revati Bhua's self-sacrfice renders Kusum's martyrdom "ultimately pointless" (46). 
For Bachan Singh and Gandhi, in other words, both in reality and in the literature that drew its inspiration from real events, the concern appears to be the preservation of women's chastity. But this is no simple matter of tradition; rather, for both, chastity and family honor are bound up with cultural community- and national-honor. The repeated exaltations of women's chastity by Gandhi and many others also shaped how abductees were received after they were repatriated. In many cases, the repatriated women were rejected by their families and communities because they had been touched and, therefore, were to remain "untouchable" for the rest of their lives. Baldwin's short story "Family Ties" (1996) captures the agony of women who fell into the hands of the enemy, and were later repatriated to India.

\section{THE WOMAN WHOSE "NAME WAS NEVER TO BE SPOKEN"}

"Family Ties," in Baldwin's collection of short stories entitled English Lessons and Other Stories, is set during the 1971 war between India and Pakistan but flashes back to the events of 1947-48. ${ }^{14}$ (The Indo-Pak war of 1971 is an apt choice since this war re-partitioned the subcontinent with the breakup of Pakistan and the emergence of Bangladesh as a sovereign nation. The violence that accompanied these events revivified memories of 1947 that many had tried to suppress.) The ten-yearold anonymous narrator is surprised to learn that she has a paternal aunt, Chandini Kaur, whose name and existence had previously gone unmentioned. Curious about her missing aunt, the narrator discovers that in 1947, eighteen-year-old Chandini, a Sikh woman, was abducted by Muslims from her home in western Punjab. By the time she was "recovered" by social workers, she had been converted to Islam and had given birth to a baby boy. Renamed Jehanara Begum after her conversion, she contacted her brother, the narrator's father, but he refused to acknowledge her. So, in order to make herself acceptable to her family, Chandini-Jehanara killed her child. Still, her brother did not relent. He merely "sent her money, told her his sister was dead and he was sorry for her troubles and to trouble him no more" (30). Subsequently, she lapsed into insanity. Her story is a cautionary tale for the young narrator, and framing Chandini's story is a chilling exchange between the narrator's father and her brother, Inder, concerning the ten-year-old narrator's "safety." Set in the context of the Indo-Pak war and taking as its subtext the wartime victimization of women, the narrator's father hands his son a revolver and instructs him: "[T] here is a war now, and I want you to know how to use it to defend this little kukri [chicken] ... If the Muslims come and your sister is in danger, you must shoot her rather than let her fall into their hands" (1996: 25-6); to which Inder responds, "I will" (26). While the narrator's father had failed with his sister Chandini, with his daughter, he will take no chances - if his daughter lacks the courage to die at the

\footnotetext{
${ }^{14}$ For a detailed discussion of this story see Mookerjea-Leonard (2017).
} 
"right" time she will be murdered by her brother before her abduction/violation can smear the family's reputation.

For women like Chandini-Jehanara national Independence is a tale of trauma. The country's freedom is inseparable from the loss of homeland through Partition, the loss of control over their bodies in the violence surrounding Partition, and, finally, their loss of home through the betrayal of their families. The predicament of the women who died, or were killed, to preempt violation and preserve family honor as well as of those who suffered rejection by the family after the fact, both present the family as a site of risk to the wellbeing of women. The young narrator in "Family Ties" sums it up thus: when troubled by the conversation between her father and brother about taking her life, she remarks that, compared with the perils of the war outside, "far more is the danger from those within" (26). For Chandini-Jehanara home proves a place of impossible longing. Desperate to return, she underestimates the potency of her (patriarchal) family's investment in her chastity, mistakenly believing that her Muslim son is the sole impediment to her restoration. Her tragedy is her failure to realize that, as an abducted and violated woman she has lost, irrevocably, her home, her nation, and her religion. ${ }^{15}$ At this time of escalating communal hostilities, any contact between a Sikh (or Hindu) woman and a Muslim man, including coerced intimacy, was regarded as a betrayal, since it was along religiously defined lines that the country was partitioned. In other words, a woman's citizenship was made contingent not only on her residence in the right country, and following the right religion, but also, on her possessing the right (chaste) body. Discussing the unacceptability of violated women within the new national community, Sangeeta Ray writes,

The raped female body encompasses the sexual economy of desire that is denied the mythologization of the purity of one's own ethnic, religious, and national gendered subject. ... Those who survive rape are refused entry into the domestic space of the new nation. This denial of legitimate gendered subject positions in the new nation is deemed necessary, for ... 'nations are symbolically figured as domestic genealogies.... The purity of the family mirrors the purity of the nation, and the raped woman cannot be the vehicle of the familial metaphor that enables the narration of the nation. (135-36)

The anxiety around the loss of women's chastity was not driven by a concern for women's wellbeing, but by the shame of what was perceived as failed manhood, a political form of castration anxiety. After all, the protection of women constitutes one of the fundamental functions of patriarchal masculinity. But here this traditional conception and traditional religious endogamy is crossed by a nationalization of the notion of family "honor." Rather than ensuring the safety of women, this new

15 The rejection of violated women is mentioned in passing in What the Body Remembers, with, "The silent women are the ones who were raped; even widows pity their kismat; families with any sense of izzat are not likely to take them back" (Balwin 1999: 440; italics in original). 
notion was concerned with preserving male prestige against men of the opposed political-national lineage. The point is illuminated further in Baldwin's story by the domestic help Nand Singh's repeated mentions of "your father" when the narrator questions him about Chandini: "For your father, she is dead"; "Any sister of your father's would have died before allowing herself to be called Jehanara Begum"; "She was dead for your father"; and "[N]o woman of your father's family would have allowed herself to become a Musalmaan and then to have a Musalmaan's child" (1996: 29-30; emphasis mine). For Nand Singh, the victim is not Chandini-Jehanara, but her brother, as her abduction was a source of disgrace for him. He was clearly overpowered by his sister's abductors, and failed to protect her. Chandini-Jehanara's brother and his devoted employee Nand Singh blame her for lacking the courage to die at the right time, with Nand Singh stating blatantly that, "She should have taken her own life when she had her wits" (30). For her brother, who cannot be fully exempted from responsibility for the murder Chandini-Jehanara commits and her loss of sanity, she is unsafe, except as a memory which her brother has preserved for almost a quarter of a century in the form of her photograph from 1947. She is allowed to be present in his life only in that time-frozen way. By thus possessing her image, he remains Chandini-Jehanara's custodian for life, controlling the discourse around her absence. He exercises this control by withholding her story even from his children before he "locks the Moonlight Princess away again in his steel almirah" (26). Protected in the steel armoire and in his memory, Chandini-Jehanara can no longer sully his family honor! His actions also reveal some residual guilt. For he has not only preserved her photograph but also the letter informing him of her recovery by the Indian state and her contact information. Chandini's transformation into Jehanara represents the triumph of the Muslims over Sikhs, and therefore, of the rival nation Pakistan over India. And to preserve community and national pride, Chandini-Jehanara must be expelled/forgotten - "Her name was never to be spoken again in this house" (29). Through the preemptive killings of women and the expulsions of violated women, women's chastity was perpetuated as a sign of national probity, and demarcated the nation's spiritual boundaries. ("Family Ties" counters Gandhi's commemoration of the preemptive deaths of women, with the narrator asking, "Is it worse to be caught, converted, killed or raped by Muslims than to be killed by a brother?" [26].)

Whereas the narrator's aunt is preserved as a chaste woman inside the armoire, her part-Muslim cousin is never acknowledged to have lived. ChandiniJehanara's son is a standing reminder of Sikh men's failure to protect their women. Her brother is burdened by shame, and comes to terms with his failure by denying her survival. This part-Muslim male child claiming the love of his Sikh mother embodies a continued threat to the Sikh man's assertion of privilege over his woman.

Chandini's rejection by her family is reinforced by the community, embodied, in this case, in the figure of the domestic help Nand Singh. Singh dismisses any connection between Chandini-Jehanara and his honorable employer saying "They found a woman whose name was Jehanara Begum and who said she was your father's sister, Chandini Kaur ... It was a lie, of course" (29); and that "[N]o woman of your father's family would have allowed herself to become a Musalmaan and then 
to have a Musalmaan's child. So I came back and agreed with your father that she must be an imposter, for she couldn't possibly be his sister" (30). Devoted to his employer almost to a fault, Nand Singh does not hesitate to assign base motives to Chandini-Jehanara's desire to return to her family: "Who knows, maybe she was mad, maybe she wanted a share of this house he got in compensation for Thamali, or who knows what she wanted" (30). He remains unmoved by her agonized desperation. The employee Nand Singh speaks not only as a loyal dependent but also as a member of the Sikh community. Since the community demands the nullification of the "fallen woman," Singh abets the process of disowning Chandini-Jehanara.

Chandini's transformation into Jehanara represents to the Indian nationalist patriarchy the triumph of the Muslims over Sikhs, and therefore, of Pakistan over India. And as a means to protect and preserve community and national pride, Chandini-Jehanara must be expelled. The genealogy of this idea reaches back to the period of anti-colonial nationalism, when women's chastity was made central in defining the sacredness of the emerging nation, by a transfer of the symbolic purity of the nation onto the bodies of women. While the discursive production of sexual purity as part of a political ideology of gender predates British colonization, in the period of anti-colonial nationalism, chastity acquired a new significance and was regarded as a political pre-requisite for inclusion in the nation. Women's chastity became a site of a struggle of discourses on manhood, nationhood and ideal citizenship. By the same logic a woman violated by the rival community, unless excluded, represented the fallen nation. Through the pre-emptive killings of women and the expulsions of violated women, women's chastity was perpetuated as a sign of national probity, and demarcated the nation's spiritual boundaries. The development of the idea of an inviolable national space that was the purity of women simultaneously enabled the colonized man, provoked by the colonizers' charges of effeteness and effeminacy, to recuperate, in some measure, his threatened masculinity. According to this modern nationalist patriarchy, it was by extending a pledge of fierce protection and regulation of women's chastity that they exercised a vigilance that they had failed to perform on behalf of the motherland.

\section{CONCLUSION}

Women in South Asia have suffered ethnocidal violence at the time of Partition, during the Bangladesh War, in Kashmir, and in the interminable series of inter-community riots that have marked the subcontinent's modern historical experience. In a fundamental, if disturbing and frightful sense, this political rape is embedded within conceptions of home and domesticity, so that these sites themselves, conventionally conceptualized in terms of nurturance, are illuminated in their more brutal aspects by the texts under consideration here. Shauna Singh Baldwin's writings draw attention to the negotiations of national borders performed on the bodies of women, and, especially, of Sikh women. The crucial issue she raises is that of the gender pathology at the heart of South Asian modernity. Although conditioned by the experience of colonialism, this mass-psychological malaise, has 
persisted, as her story "Family Ties" illustrates, beyond national independence, a fact literature has allowed readers to grasp with a degree of moral seriousness largely lacking in the public domain.

Reviews sent to author: 4 November 2017 Revised paper accepted for publication: 28 February 2018 


\section{WORKS CITED}

BALdw in, Shauna Singh. English Lessons and Other Stories. Goose Lane Editions, 1996.

What the Body Remembers. Nan A. Talese, 1999.

Butalia, Urvashi. “Community, State and Gender: On Women's Agency During Partition”. Economic and Political Weekly, (24 April), vol. 28, No. 17: WS 12-WS 24. 1993.

"Muslims and Hindus, Men and Women". Women and the Hindu Right. Urvashi Butalia and Tanika Sarkar eds. Kali for Women, pp. 58-81.1995.

Dasgupta, Shumona. "The Extraordinary and the Everyday: Locating Violence in Women's Narratives of the Partition" in The Indian Partition in Literature and Films: History, Politics, and Aesthetics Rini Bhattacharya Mehta and Debali Mookerjea-Leonard eds. Routledge, 2015.

Gandhi, M.K. Collected Works of Mahatma Gandhi, vols. 1-100, (E-Book or CD Rom version) Government of India, Publications Division, 1999 (1958-94).

Misri, Deepti. Beyond Partition. University of Illinois, 1994.

Menon, Ritu and Kamla Bhasin. Borders and Boundaries: Women in India's Partition. Rutgers University Press, 1998.

Mookerjea-Leonard, Debali "To Be Pure or not to Be: Gandhi, Women, and the Partition of India." Feminist Review 94, 2010, pp. 38-54.

Literature, Gender, and the Trauma of Partition: The Paradox of Independence. Routledge, 2017.

Pandey, Gyan. Remembering Partition: Violence, Nationalism and History in India. Cambridge University Press, 2012.

RAY, Sangeeta. En-Gendering India: Woman and Nation in Colonial and Postcolonial Narratives. Duke University Press, 2000. 